\title{
Malaysia's Refugee and Asylum-Seeking Children: A Child Rights Perspective
}

\author{
Abdullah Khoso1, Hanafi Hussin ${ }^{2,3 *}$ \\ ${ }^{1}$ Department of Gender Studies Programme, Faculty of Arts and Social Sciences, University of \\ Malaya, Jalan Universiti, 50603 Kuala Lumpur, Wilayah Persekutuan Kuala Lumpur, Malaysia. \\ ${ }^{2}$ Department of Southeast Asian Studies, Faculty of Arts and Social Sciences, University of Malaya, \\ Jalan Universiti, 50603 Kuala Lumpur, Wilayah Persekutuan Kuala Lumpur, Malaysia. \\ ${ }^{3}$ Universiti Malaya Population and Migration Research Centre (UMMPRC), University of Malaya, \\ Jalan Universiti, 50603 Kuala Lumpur, Wilayah Persekutuan Kuala Lumpur, Malaysia.
}

Received: 28 January 2020; Revised: 30 July 2020; Accepted: 28 September 2020

\begin{abstract}
This article has exhibited the child rights framework's relevance while assessing and analysing voiceless Malaysian refugee and asylum-seeking children's status. The secondary data has been segregated, themed and analysed under the child rights framework related to refugee and asylum-seeking children. The article argues that refugees and asylum-seeking children in Malaysia are treated as outsiders and threats to the social fabric; this rhetoric against refugees and asylum-seeking children has shaped Malaysia's excluded legal and social treatment towards such children. It has also exacerbated the painful and excluded experiences of such children. The article also argues that only frameworks do not bring the desired results if the state constantly thrives on racialised politics. The analysis shows these children are subject to various social, economic, political, legal and normative issues, which have compelled them to live a quite stressful and challenging life. These children's difficult experiences show serious deficiencies and problems in the government structures and functions, which this article believes are the desired outcomes of Malaysia's legal, political and social approach towards these children. The analysis also indicates that the UNCRC's child protection systems and mechanisms (and the international community) are also unable to pursue the state to stop it making its independent choices in matters dealing with a vulnerable group of children and recognising them the rights holders rather as threats. The complexities and challenges in implementing such children's rights also lie in the roles of the two separate mandate holders (i.e. UNHCR and UNICEF).
\end{abstract}

Keywords: Child Rights Framework; Refugee; Asylum Seeking Children

How to Cite: Khoso, A., \& Hussin, H. (2020). Malaysia's Refugee and Asylum-Seeking Children: A Child Rights Perspective. Otoritas : Jurnal Ilmu Pemerintahan, 10(2), 97-119.

Permalink/DOI: https://doi.org/10.26618/ojip.v10i2.4639

${ }^{*}$ Corresponding Author.

E-Mail : hanafih@um.edu.my

Copyright (C) 2020, Otoritas : Jurnal Ilmu Pemerintahan, ISSN: 2088-3706 (Print), ISSN: 2502-9320 (Online) 
Available Online at https://journal.unismuh.ac.id/index.php/otoritas

Otoritas : Jurnal Ilmu Pemerintahan, 10 (2), October 2020, 98

\section{INTRODUCTION}

By February 2017, the United Nations High Commissioner for Refugees (UNHCR) had registered some 149,500 refugees and asylum-seekers in Malaysia, including 35,144 children below 18 years of age. Of the total, 67 per cents were men and 33 per cent women (see Table 1) (UNHCR, 2017). The numbers keep growing with rising human rights crisis within South Asia and the Middle East regions. In Malaysia, the real numbers of refugee and asylum-seeking children may be higher since these figures belonged to people who had willingly registered with the UNHCR. Irrespective of the lack of reliable data on refugee and asylum-seeking children, this research would like to use a child rights framework to understand the life of refugees and asylum-seeking children in Malaysia. There are a few studies on refugee and asylum-seeking children in Malaysia. For instance, the available studies (Allerton, 2014; Siah, Lee and Goh, 2015; Allerton, 2017; Razali, 2017) on ref- ugee and asylum-seeking children in Malaysia provide important substance for understanding the matter. However, they have ignored the child rights framework in their analyses.

Therefore, the main objective of this study is to analyse the status of refugees and asylum-seeking children in Malaysia in the light of the child rights framework, which is based on the United Nations Convention on the Rights of the Child (UNCRC), General Comment No. 6 of 2005 (Pobjoy, 2013) and the Committee on the Rights of the Child's (henceforth the Committee) Concluding Observations and Recommendations (CoRs) (in 2007). The Committee (a group of independent international experts on child rights) oversees and monitors the compliance of the UNCRC, including the rights of refugee and asylum seekers children in any country (Lundy, 2007). General Comment No.6 is about the treatment of unaccompanied and separated children out of their country of origin (UNICEF, 2006). Through the child rights framework, this research is

Table 1. Total Refugees And Asylum Seekers Registered with the UNHCR Source: UNHCR (2017)

\begin{tabular}{llc}
\hline $\begin{array}{l}\text { Total Refugees and } \\
\text { asylum seekers from }\end{array}$ & Rohingyas & 56,458 \\
Myanmar & Myanmar Muslims & 39,684 \\
& Rakhines \& Arakanese & 10,454 \\
& Others & 4,611 \\
& Total refugees and asylum seekers from & 133,263 \\
& Myanmar & \\
\hline Refugees and asylum- & Pakistanis & 3,058 \\
seekers from other & Sri Lankans & 2,626 \\
countries & Yemenis & 2,008 \\
& Syrians & 1,878 \\
& Somalis & 1,858 \\
& Iraqis & 1,456 \\
& Afghans & 844 \\
& Palestinians & 687 \\
\hline Grand Total & Others & 1,818 \\
\hline
\end{tabular}


better positioned to investigate the moral and political claims, which other studies (with the general context of analysis) are weak to offer. It would especially look into the inconsistencies between the policy and practice of the implementation and the proofs of policy implementation and practice in the child rights context. At the same time, this article offers an appraisal of Malaysia's progress on refugee and asylum-seeking children's wellbeing, which is one of the indicators of progress towards implementing the UNCRC in the context of vulnerable groups. Most importantly, this article will attempt to exhibit the child rights framework's relevance while assessing and analysing Malaysian refugee and asylum-seeking children's status.

\section{LITERATURE REVIEW}

Generally, refugee and asylumseeking children are debated in the context of political, social and moral recognition and status. Allerton (2017) conducted fieldwork with children of migrant and refugee families in Kota Kinabalu in Sabah. She looked the matter of stateless, refugees and asylum-seeking as an issue of recognition from a social and political perspective. Razali (2015) discussed the matter mainly within the paradigm of the UNHCR's conventions but set aside the child rights specific approach to the matter. Razali (2015) has highlighted various significant challenges and hurdles as Allerton (2017) has analysed the issue from a social and political perspective, but they have not considered the child rights framework in their attempts. Razali has analysed the problems of all refugees in Malaysia whereas Allerton has offered an analysis of the issue only in the Sabah context. Also, many other studies (Kaur, 2007; Kaur, 2008; vas Dev, 2009; Khairi, 2012; Supaat, 2014- a few to mention) have taken into general perspectives to study the overall state of refugee and asylum-seeking children in Malaysia. Such studies have not given attention to children's concerns, issues, and problems from children's rights perspective, refugee children's rights framework, and rights holders.

Khairi (2012) briefly highlighted the situation of all refugees in light of the Malaysian laws. In general, he has emphasised on challenges and actors' role to be engaged to protect refugees' rights. Like Khairi, Supaat (2014) has followed the common pattern of analysing refugee children in Malaysia and has provided a great insight into the national laws (and gaps in the laws), which render refugee and asylum-seeking children vulnerable, but he too lacked the child rights framework (prescribed in the UNCRC and other documents) in analysing the overall situation of refugee and asylum children. They had primarily discussed the issue from a Malaysian law perspective. Kaur (2007 and 2008) has paid attention only to the policy and governance in Malaysia. Thus, he lacked to provide the assessment of Malaysia refugees and asylum seekers in a fuller manner by using the child rights framework. Despite lacking child rights framework and other necessary points, especially the fundamental principles of child rights (such as the best interest and non-discrimination), these all studies have ample substance that also strengthens the argument on different policy and practical measures.

\section{RESEARCH METHODS}

In a quest for answers to the research objectives, the literature review approach is used, which is based on the secondary sources; which include research articles and reports on refugee and asylum-seeking children in Malaysia by the media, UN agencies, NGOs, INGOs, and academia only in English from 1995 (when Malaysian ratified the UNCRC) to date. These sources provide the vital substance and the context to underscore the political, cultural, economic and social 
process, practices and perspectives (such as child rights). The data has been searched through a google search engine, and research articles and books were referred from the library. It primarily follows the UNCRC (its articles and principles as a frame of reference) and its themes and uses the secondary data to analyse the ground realities. In light of the main themes given in the UNCRC related to refugee and asylum-seeking children, the data has been segregated, themed and analysed. These themes include data collection and monitoring, birth registration, policy and legislative framework, and the right to education and health. In addition to these themes, the new matters have surfaced in the secondary data, which includes compliance with the United Nations Committee on the Rights of the Child's recommendations on refugee children and the complexities surrounding the refugee children's asylum status. In this day and age, civil society organisations and the media often produce valuable content on refugee and asylumseeking children's conditions in Malaysia. This content has enabled the researchers to critically understand the link between international obligations and the measures taken by the state to address the matters and ground realities in which refugee and asylum-seeking children live. However, as indicated above, the academic discourse on the refugee children's rights perspective is lacking, which this article would like to address.

Why this article uses the child rights framework? It is because, with the use of the child rights framework, the article wants to fill the existing gap in understanding the ordeal of the Malaysian refugee children and dealing with the situation in a fuller manner. Since Malaysia is a party to the UNCRC, therefore, the UNCRC and the Committee's CoRs are better to enlighten us to understand the obstacles and possibilities in realising the rights of refugee children at the grassroots level and also recognise/identify the institutional structures and processes responsible for ensuring the rights of refugee and asylum-seeking children. The analysis conducted through the child rights framework will enable the response to the specific needs, and the risks refugees and asylum-seeking children face in Malaysia. These needs include protection from discriminations, abuse, neglect, violence, and exploitation and providing access to basic services, and sustainable solutions in refugee and asylum-seeking children's best interest (UNHCR, 2008). The framework recognises children as rights holders. It is about a child protection system that subsumes measures by the duty bearers for the right holders at the families, communities, local (provincial or state), national and international levels to reduce the risks and respond to children's protection needs. It enables us to look at the governments' benchmarks to strengthen their performance or measures to protect children through continuous engagement with the communities and the permanent child protection systems (UNHCR, 2012). The UNCRC provides procedural guidelines and guarantees, which considers the international refugee law (Pobjoy, 2013). Article 22 of the UNCRC is directly talking about the rights of refugee and asylumseeking children. It demands the states to take adequate measures to protect children (companied by parents or unaccompanied) who already received refugee status or seeking for it. The states will also work together with the UN to provide the same rights related to protection, development and survival as other national children have been receiving (OHCHR, n.d. Online).

The UNCRC is used as a tool to influence government policies (Lundy, 2012) and to interpret refugee and asylumseeking children's rights (Pobjoy, 2013). The child rights framework provides an adequate context of/for textual analysis. It encompasses almost all normative 
(human rights) dimensions to be assessed. It also helps to correlate the social, cultural, political, economic and religious ground realities with laws, policies, financial allocations, and administrative measures in Malaysia (Vandenhole et al., 2015). The assessment through this framework is indispensable to understand the refugee and asylum-seeking children's rights in perspective, in which, their rights are texted (or intertextualised) (Pobjoy, 2013). In the following, findings are presented under different themes appeared in the secondary data and the UNCRC.

\section{RESULTS AND DISCUSSION}

Compliance with the Committee's Recommendations

In 1995, Malaysia ratified the UNCRC. Afterwards, in 2006 Malaysia submitted its initial report to the Committee. Not satisfied with this initial report, the Committee urged Malaysia to submit a combined (the second, the third and the fourth) report to the Committee by March 2012 (Committee on the Rights of the Child, 2007). However, the report was still not submitted by the end of 2018 the only report that has been presented so far, information on children of refugees, migrant workers, and asylum seekers. A short paragraph in the report mentions that Malaysia did not ratify the 1951 Refugee Convention (on the Status of Refugees), but it has often followed the international customary laws related to refugees and displaced people (Committee on the Rights of the Child, 2006: 88) and that the individuals entering Malaysia as refugees have invariably been given support on humanitarian grounds.

Moreover, the Malaysian government insists that it has always extended full cooperation to the UNHCR. In specific, the reported cited that in 2005 the Attorney General of Malaysia issued instructions to immigration authorities to refrain from prosecuting asylum seekers and refugees holding the UNHCR cards. The government has also shown willingness to decrease medical fees for refugees and asylum seekers and access the UNHCR to detention centres (Committee on the Rights of the Child, 2007).

Despite these assurances by the government, the Committee expressed concerns about the non-availability of the legal framework to protect asylum-seeking and refugee children in Malaysia. It regretted that Malaysia had not acceded to the 1951 Convention on the Status of Refugees and its optional protocol (1967). Moreover, the Immigration Act 1959/63 (Act 155) provisions often resulted in forced detention and prosecution of refugee and asylum-seeking children and their families. The Committee recommended that Malaysia should use General Comment No. 6 (2005) on the Treatment of Separated and Unaccompanied Children Outside their Country of Origin while dealing with refugees and asylum seekers. It also recommended the development of a legal framework for the protection of refugee and asylum-seeking, especially unaccompanied and stateless children, in light of international child rights standards. Lack of access to formal education to refugee children from Myanmar who were living in Malaysia since the 1990s was also raised as an issue of grave concern (Committee on the Rights of the Child, 2007: paragraph 83). The CoRs reveal that Malaysia has to take many measures to comply with the Committee's recommendations to protect refugee and asylum-seeking children and their families' rights.

Contexts and Complexities Surrounding the Refugee and Asylum Status

From Pakistan, asylum seekers children came along their families because of fear of persecution in the context of their faith. However, Iraqi and Yemeni children along with their families, run away from 
war, hunger and poverty in their countries. Rohingya had fled the country because of the massive scale of atrocities by the state authorities. In Malaysia, refugee and asylum-seeking children's issues and problems varied area by area (such as Sabah and Selangor) within Malaysia (and also community by community). For instance, asylum seekers from Pakistan may not have serious economic issues as Rohingyas might have. Since refugees and asylum seekers from Pakistan are often supported by their community members and relevant faith-based organisations such as Qadianis (Palansamy, 2018). For studying these contexts and issues of each community, another comparative study is required, and this review is unable to take on these broad areas.

However, in Malaysia, the majority of refugee and asylum-seeking children and their families have certain common issues. Their problems also arise how Malaysia defines and treats non-Malaysians (excluding the expats and students) in its laws and policies. The UNHCR has defined a refugee as a person who has left the home country and joined the host country because of war, conflict, and the fear of persecution. The fear of persecution may be for reasons of religion, nationality, race, membership of a particular group or support to specific political opinion (UNHCR, n.d. (a) Online). It defines asylum seeker as a person who left or ran away his or her country, sought sanctuary in the host country, and applied for asylum (UNHCR, n. d. (a) Online). In the absence of Malaysian pro-refugee and asylum-seeking laws and policies, refugees and asylum-seeking families are called or labelled under different categories or tags, which has increased complexities for the charitable organisations to deal with issues of diverse non-Malaysian refugee and asylum-seeking communities according to their tags/status. They are also recognised as stateless or at risk of statelessness. Allerton (2014) believed that the stateless people included Malaysians of Indian origin, Rohingya refugees from Burma, nomadic and boat-dwelling Bajau Laut/ Sama Dilaut communities, and the children of refugees in Sabah, in the North Borneo. However, in Table 1, we see that the UNHCR considered Rohingya from Myanmar as refugees like many other refugees from Asian and Middle Eastern countries, but Allerton considered them stateless.

However, it is observed that these people are tagged as refugees, asylum seekers, migrant workers, undocumented, and stateless. Irrespective of these categories, refugee and asylum-seeking children are undocumented, stateless, and workers. They did not have a national identity (Malaysia birth certificates) because they were born to refugee and asylum-seeking parents. Thus, they were stateless. They had no documents (except the UNHCR card), they were undocumented, and since many of them had to work for a living, thus, they were migrant workers. Another point to this categorisation of refugees and asylum seeker is that they can all be stateless (without document and identity) but not all stateless could be refugees and asylum seekers. For instance, Bajau Laut is stateless living in Malaysian waters for decades (Acciaioli, Brunt, and Clifton, 2017), but they are neither refugees nor asylum seekers. But sometimes, they are treated like migrant workers (Hussin and Khoso, 2017). In September 2018, the United Nations expert on the rights of the child had an eight-day visit from Malaysia to understand the state of the rights of children in the country. At the end of her visit, she had shown serious concern on a few aspects including the state of stateless children, but she mixed the stateless children with refugee and asylum-seeking children (Aiman, 2018, October 1).

In Malaysia, according to the UN$\mathrm{HCR}$, there is a difference between refugees and asylum seekers. Those people 
are refugees who have been verified by the UNHCR through its refugee status determination (RSD) process, but asylum seekers had applied for refugee status but had not been through the complete RSD process (The Star Online, 2018, October 21). In the past, the UNHCR used to provide identity cards to both asylum seekers and refugees, but that practice stopped. Families seeking refugee status aim to return to their country of origin unless issues in their home countries are resolved (such as war) but those who want to stay in Malaysia (or want to go to another country- other than their country of origin), they apply for asylum through the UNHCR. Those people who do not fit into the UNHCR's criterion (definition) of refugee, they are treated as asylum seekers. The UNHCR claims that they assess whether they needed the UNHCR's protection as a refugee. The question is, what happens to children when the complexities surround to their status and when they are neither recognised as asylum seekers nor refugees in Malaysia. Chin community members feared that the UNHCR would take away their refugee protection status, which resulted in their depression and suicidal intentions (The Star Online, 2018, October 21). Generally, asylum seekers are asked to prove whether they were persecuted or they had a fear of being persecuted. In other words, these people have to prove the sufferings and trauma they had went through (Joles, 2018, September 25).

The complexities and sufferings of refugee and asylum-seeking children and their families are the outcomes of various practices, which, the UN expert believed, primarily originated from the lack of strengthened laws and policies (Aiman, 2018, October 1). The Committee had recommended Malaysia to comply with the legal obligation given in the UNCRC and provide protection to all children in the law irrespective of the nationality, the stateless or stateless status of the asylum- seeking and refugee children (Committee on the Rights of the Child, 2005). For addressing the complexities and bringing an end to the sufferings of such children, the UN child rights systems and mechanisms have not adequately been asserted and pursued. In the following narrative, the article will draw specific attention to the UN's role in asserting for the rights of refugee and asylum-seeking children.

\section{Data Collection and Monitoring}

The UNCRC does not have a specific article on data collection. However, it keeps asking the states to provide sufficient information related to children's rights (see Article 44 (2)). Sufficient information is only possible if the states have been collecting data on every aspect of children's rights. The Committee (2007) had urged Malaysia for setting up a mechanism and system to collect the data in a comprehensive manner of all children, including refugee and asylum seekers. However, Malaysia lacks the exact data on refugees and asylum-seeking children. The absence of exact data on refugee and asylum-seeking children has a serious impact on various matters, including the effective and systematic monitoring of their rights and devising and planning policies and programmes on refugee and stateless children. In this respect, the Committee's recommendations related to data on asylum seekers and refugees children have not complied yet. However, whatever the data on refugee and asylum seekers is available that is collected by the UNHCR (UNHCR, 2017). It is merely because most of the asylum seekers and refugees attempted to register with the UNHCR to seek some protection from the arrest, detention, deportation, and humiliation. The UN's mechanism somehow protects them.

In August 2017, the UNHCR confessed that the refugees and asylum seekers registration process had slow down and in July 2017, only 300 asylum seekers had registered with it. The Malaysian Min- 
istry of Home Affairs had sent an alert to ghost refugees for registering under the Tracking Refugees Information System. The ghost refugees also include 150,000 refugees holding the UNHCR cards (Tan, 2017). The slow process, complexities, and intricacies around the registration of refugee and asylum seekers also affect people's rights, especially of children, going through the process. The UNHCR has paid insufficient attention to such children (Human Rights Watch, n.d.). Therefore, such communities have often raised voices against "failed" (Bernama, 2019, June 19) role of the UNHCR in protecting refugees and asylum seekers' rights. The non-cooperative and non-supportive attitude of the officials at the UNHCR has rendered people to be exploited in the destination country (Borneo Post, 2016, December 31).

\section{Problems of Birth Registration}

Birth registration is one of the fundamental rights of children (Article 7(1) of the UNCRC). It is an official recording of a child's birth, which ensures and protects the identity (name) and provides the right to acquire a nationality (Article 8 of the UNCRC). The birth registration also helps the children to identify their parents and to be cared for by them. A child born to refugee or asylum seeker is still refugee and asylum seeker, and he or she would not be a Malaysian national. They are stateless without documents and national identity. Their problems are the outcome of the Malaysian legislative framework, and the current legal framework is the outcome of legislators' lack of will to amend the laws. In 2014, the UNHCR introduced a campaign called IBELONG and put statelessness on the human rights agenda. It aimed to address the problem in less than ten years (UNHCR, 2014). The UNHCR believed that statelessness could be addressed by doing minor changes in the law and introducing practical measures at the national level. Those measures included birth registration and amendments in the nationality related provisions of the laws so that children could acquire nationality in the state where they were born (Allerton, 2017). However, the Constitution of Malaysia allows a stateless child to be national of the country, but such a child has to meet a jus sanguinis principle of citizenship. According to this principle, a child born in Malaysia is not a citizen of the other country and cannot get citizenship of another country by registering within one year of birth (UNHCR, 2013). The practical side of this legal dimension offers quite contrasting facts, which did not get proper attention from the perspective, in which, it deserved to be investigated. But on the other hand, there is the principle of jus soli (the law of the land), which allows citizenship to those born in the country. When the principle of jus sanguinis is not granted the priority, it implies that the UNCRC's principles of best interests of the child are not given the paramount importance (Sawyer, 2013) but the political fears and marginalisation of the locals are given primary considerations (Palansamy, 2015).

Article 14(1) (b) Part II (1) (e) Second Schedule of the Federal Constitution has been viewed as exemplary legislation to stop statelessness (as mentioned earlier many of the stateless people are refugees and asylum seekers). However, the protections in Article have not been provided to various children with stateless, refugee or asylum-seeking status or at risk of going to be stateless in the country. The article says that a child born in Malaysia is a Malaysian citizen if the person "is not born a citizen of any country." Unambiguously, Malaysia does not recognise the existence of stateless children (Chou and Gooch, 2016). In 2015, the BBC's report showed that 100,000 children were without identity documents in Malaysia (Pak, 2015). Children abandoned in homes run by the social welfare depart- 
ment do not have identity documents. They are issued with birth certificates. However, their status remains noncitizen, even though they are not "born a citizen of any other country" (Today Online, 2018, December 12).

Some children in the welfare homes set up by the social welfare department (known as JKM) are also without birth certificates or any documents to confirm their citizenships. They remain noncitizens. At the age of 12, children received the green MyKas identity cards declaring them "persons of undetermined citizenship," which were issued to transitory residents. The National Registration Department had not laid down any process to settle the issue of such children's citizenship status. When these children turn out to be 18 , they were freed to go out of the homes with undetermined citizenship. Instead, upon turning 18, many residents of the JKM homes are released with undetermined. Due to official intricacies, bureaucratic procedures and financial issues, many former residents of the homes have not received MyKas identity cards or Malaysian citizenships. Ultimately they become "illegal immigrants" under Malaysia's laws (Child Rights Coalition Malaysia, 2012).

Many children of Indonesian and Filipino descent born in Sabah Malaysia did not know their countries of origin. Filipino could not register their children's birth in the absence of a permanent Pilipino consular in Sabah. Malaysians do not like the Philippines' Consulate for the Philippines' political and controversial claims on Sabah (Tregonning, 1970). However, the Philippine Embassy claimed that it provided mobile consular missions in different locations of Sabah. In Kota Kinabalu and Tawau areas of Sabah, the Indonesian embassy has provided a consulate, which provides the identity documents for Indonesian parentage children. However, for some families, it is highly expensive to reach the consulate. The stateless children of Rohingya and Palestinian refugees have not been able to get citizenship anywhere. The majority of them were living for many years in Malaysia, but without basic services (Child Rights Coalition Malaysia, 2012). Bajau Laut children resided mainly around the east coast of Sabah were also at a greater risk of statelessness. The status of statelessness renders these children "vulnerable to abuse, exploitation, and marginalisation from mainstream society" (Child Rights Coalition Malaysia, 2012: 24). As indicated above, Bajau Laut was treated like migrant workers (Hussin and Khoso, 2017).

The Child Act 2001 of Malaysia is not concerned with the matters about children born to refugee and asylum seekers parents in Malaysia; however, the UNCRC prohibits discrimination on any grounds including the nationality. The Act is also least concerned with children's best interest in citizenship and immigration (Sawyer, 2013). There are also concerns that refugee and asylum-seeking children born in Malaysia have to apply for citizenship with the National Registration Department (NRD). It is believed to be a long and exhausting process minimally takes two years for an application to be processed. In most cases, applications were rejected without giving any reasons (Azizan, 2018).

\section{Problems of Policy and Legislation}

In March 2015, the Minister in the Prime Minister's Department had told the Parliament that Malaysia was not intending to ratify the Convention Relating to the Status of Refugees (1951) and the Protocol Relating to the Status of Refugees (1967). The Minister blamed that the migrant workers, refugees, and asylum seekers had brought problems and the situation had worsened in the country. The refugees had become economic migrants, and they took away the locals' businesses. The Minister feared that the country would not be able to comply with 
the necessary responsibilities under the 1951 Convention and the optional protocol, and refugees and migrant workers would create more problems in Malaysia. He added that the government was not willing to encourage refugees and migrant workers in the country (Palansamy, 2015). In 2015, the Minister of Women, Family, and Community confessed that the national policy did not match with the UNCRC about refugee and migrant workers' children (Mayberry, 2015).

Child Rights Coalition Malaysia highlighted that Malaysia has neither ratified the Convention on the Status of Refugees (1951) and its Optional Protocol (1967) nor made legal and practical improvements for asylum-seeking and refugees children and their families. Instead, they are treated as irregular migrant children. Thus, they are deemed as "illegal immigrants" under Malaysia's Immigration Act of 1963. Therefore, they are often vulnerable to arrest, detention and prosecution (Child Rights Coalition Malaysia, 2012: 22). Allerton (2018) based on her fieldwork in Kota Kinabalu (in 2012-2013) wrote that Malaysia's politics, immigration policies, practices and the regional history of Sabah had worked together to construct a social environment in which the descendants of stateless, refugees and asylum seekers were living as impossible children.' These children were impossible to be educated, regularised and recognised as moral citizens of Sabah. The concerned Malaysian authorities did not pay much attention to the issues of stateless and refugee children. Thus, they lived invisible lives under the liminal legality. The IMM13 visa permits for refugees in Sabah allowed them to live in the country and work in certain economic areas, and these visas are renewed every year through a lengthy process. There was no debate on long-term robust solutions for a refugee. However, the high cost of renewing IMM13 visas bared some families to renew their visas; which resulted in their legal status becomes irregular.

Asylum-seeking, refugee, and irregular migrant children have grown up with extremely limited safety and stability. They were always at the risk of arrest and detention by the authorities and were kept in immigration depots (Child Rights Coalition Malaysia, 2012). The registered refugee children by the UNHCR are arrested and detained in various detention centres (including depots) in Malaysia, but those who have not registered and in the process of registration, they have to pass through a trauma (Fong, 2019; Paulsen, 2019). From immigration depots, a refugee or asylum-seeking child is released after a minimum of three months, where conditions in depots are largely terrible. Children were detained along with adults without the provisions for the protection of children and were provided with little water and food.

In the same way, pregnant women and babies were not provided special care in depots (Child Rights Coalition Malaysia, 2012). Detention of refugee and asylumseeking children were commonly practised (Suganya, 2013, October 6; Bedi, 2018 (a), October 17). During the eight days visit of Malaysia, the UN expert was shocked to see children detained with their mothers in the worst conditions in immigration detention centres (Aiman, 2018, October 1). In the media, details of some cases surface. However, the majority of refugee and asylum-seeking children and families' painful ordeal is not reported anywhere (Free Malaysia Today, 2019, July 4). The learning centres run by charitable NGOs were somehow considered safe places of refugee and asylum-seeking children. Malaysia and Indonesia have an informal agreement that children would not be arrested when they are in the learning centres. However, they remained at risk of arrest outside the school. Generally, when refugee and asylum-seeking children heard the news of a possible police raid, they did not come to school for 
many days, and they stayed in forests/ woods overnight to escape the raid and die out to stay out of prison. Children did not come under the protection of the school when they were together with their parents. That is why they had to run to places where the police could not find them. However, sometimes, children were arrested, and some lucky children were released through teachers and NGOs, but many were deported (Chou \& Gooch, 2016).

The life of refugees and asylumseeking children are tough and unprotected. They are denied the right to protection as given in Article 22 of the UNCRC. They did not merely face problems by the authorities, but the local also felt them as threat and risks, thus, in 2015, Lobang village was fired, which destroyed all homes of refugees and asylum seekers who lived with their families and children. They believed that it was an intentional act of some who gave refugees a clear message that they were not welcome in Malaysia. Among those whose houses became the subject of blazes was Jahara. She had no place to go. She had come from the Philippines three decades ago because of the war. Her son could not find a job, even though he was born in Malaysia. A local business owner shared with the BBC representative that she relied on refugees and foreign workers. However, she did like that migrant workers and their children have more rights in Malaysia because she believed that the locals would be deprived of the same rights to the migrant workers (Pak, 2015).

NGOs working on child rights have often reported that a large number of refugees and asylum-seeking were living chronic lives in Malaysia without access to rights, protection, and services because there was an extremely limited number of resettlement places offered worldwide (Child Rights Coalition Malaysia, 2012; Free Malaysia Today, 2019, July 4; Fong, 2019; Paulsen, 2019). The offspring of refugee and asylum seekers were born in Malaysia. However, they were not allowed to marry nor have children in Malaysia. The asylum seekers and refugees were living in Malaysia for generations but did not have the right to register the birth of their children because of the fear of arrest and deportation (Chou and Gooch, 2016). An ethnographic study revealed that the issue of statelessness is a broader issue of justice and human rights, and children did not merely want documents but their right to be recognised as people of the land where they were born (Allerton, 2014). Refugee children were also reported to target the stereotyped image of terrorism, especially children belonging to Iraq. The local children often bullied and teased refugee children for having a foreigner identity (Sayed \& Choi, 2018, February 5).

Malaysia lacked law or policy to regulate or govern the sizeable refugee and asylum-seeking population. The lack of such policy has barred the country from differentiating between refugees (with or without UNHCR card) and the undocumented migrant workers. Both are treated in the same manner. Consequently, they get mixed into the larger unregulated migrant workers market (Wurscher, 2018). Refugee and asylum-seeking families had a little protection even if they had the UNHCR's cards; the protection was enjoyed only if the relevant official sympathised with the refugees and understood the UNHCR system. Otherwise, they were vulnerable to "arrest, detention, prosecution, imprisonment and other criminal sanction (including caning) and deportation if not identified, registered and granted protection by UNHCR" (UNHCR Malaysia, 2015). Also, many registered with the UNHCR had no guarantee of protection from the above treatment. Although ratified the UNCRC, Malaysia did not have specific provisions in its laws to exempt refugees and asylum -seeking children from the provisions of 
the Immigration Act 1959 (UNHCR Malaysia, 2015).

\section{Everyday Lives of Refugee Children}

Refugee and asylum-seeking families often lived together in overcrowded and congested places since they could not afford expensive accommodation from their pockets. Four or five families lived in small rooms of the apartment and shared living facilities (Sayed and Choi, 2018, February 5). They could not afford money to visit nearby hospitals. Their poor living conditions put all family members at risk (Menon, 2017). It was illegal for a refugee to work in Malaysia, which resulted in them working in sweatshops and factories and engaged in other illegal works where they had no protection against abuse, exploitation, and mistreatment (Goh, 2018, January 11). The UNHCR had requested the new government to allow the refugees and asylum seekers to live and work in Malaysia (Bedi, 2018 (b), June 25).

Children's attempts to escape the police had also become fatal for them. In 2015, three teenage brothers had died when they were hiding from the police under a fish market in Lahad Datu. Three decades ago, boys' parents had come to Sabah from the Philippines. They and their other seven siblings were born in Malaysia. The community claimed that the authorities had sprayed toxic gas, which suffocated the boys, but the police did not accept it and said that the boys had already drowned before their arrival (Chou \& Gooch, 2016). In either case, the state had to look at the matter from the rightsholder perspective. It is the right to life of three innocent brothers. Moreover, neither UNICEF nor UNHCR had any follow up of the case.

Almost all refugees with the UNHCR card or without it are always scared of the police and immigration raids and arrests; their lives are plagued with this fear, which badly affected their work and edu- cation. Refugee school teachers are also arrested for not carrying the UNHCR cards. Children arrested from restaurants are kept in crowded prisons (Sayed \& Choi, 2018, February 5). Time and again, warning and alerts by the government departments (especially by the home department and the police) and continuous raids on refugee and asylum communities have created a stressful life of children and adults. The stateless children, even six years old, live in a state of fear. They remain ready and vigilant to run and escape the police and immigration authorities' raid (Sayed \& Choi, 2018, February 5). In many villages on the coastal belts, boats and palm oil plants, children hide. These children are also called hidden children, and they live most of their lives by playing a precarious game of cat and mouse with authorities. Asian foundation estimated about 50,000 hidden or stateless children in Sabah state only (Chou \& Gooch, 2016). After arrest, children were separated from their parents and detained, along with unrelated adults (Wurscher, 2018).

Many children from the Rohingya community have passed through heartwrenching ordeal and trauma in Myanmar, and they arrived in Malaysia such as Mohammad who reached in Malaysia with his mother and three siblings in 2015. His father had 'disappeared' in 2013. One day, Muhammad's family came to know that Buddhists, Myanmar had, killed his father. Later on, their house was burned down. Along with some of the other families, Muhammad's family fled to Thailand via sea across the Bay of Bengal. Mohammad family left the village at night in a fishing boat. Then they boarded a big boat that was crowded with people. In Thailand, they spent two months in a jungle camp where Muhammad's mother worked and raised money to pay the traffickers to reach Malaysia. As they arrived in Malaysia, the police arrested Muhammad's and other families. They were produced be- 
fore the court of law, which sent them to the Juru detention centre. After some months in the centre, they were finally registered with the UNHCR and were released. They were living in a shared room in Kuala Lumpur along with an old couple from Myanmar. Muhammad's family was surviving on the good wills of others. They do not have a home, security, protection, and certainty. They lived at the mercy of others (Mayberry, 2015).

\section{Refugee Children's Right to Education}

Since Malaysia had not signed the refugee convention and labelled it as the European instrument (Kneebone, 2017), refugees were viewed as illegals or undocumented migrants. Therefore, they were unable to get proper work, send their children to government schools and benefit from the government's health services (Mayberry, 2015). Malaysia had vague educational policies towards refugees, asylum seeker and migrant children living in the country. Article 28 of the CRC makes the right to education undeniable for every child and human being. However, Malaysia has made reservations that article 28 (1) (a) is inconsistent with the Malaysian constitution, domestic laws, and national policies (Makhtar, Asari and ML, 2015).

In Malaysia, no national legal provision allowed the refugee and asylumseeking children to have the right to education. They were persistently denied the right to formal education (UNHCR, n.d. (b)) because they were considered illegal (Makhtar, Asari \& ML, 2015). For some access to quality education was a serious issue. Formal education was inaccessible to them. They attended the poorly financed and under-resourced informal learning centres (Child Rights Coalition Malaysia, 2012; UNHCR, n.d. (b)). A small number of children had birth certificates, but even the ones with birth certificates had no access to government schooling. The government schools did not generally accept non-Malaysian or undocumented children. Many asylum-seeking, refugees, a stateless and irregular migrant could not afford to enrol their children in private schools. Thus they relied on education provided through informal learning centres. The centres provided very basic education to children (Child Rights Coalition Malaysia, 2012).

The UNHCR's website shows that by June 2018, 133 learning centres for refugees, and asylum seekers' children were working in Kuala Lumpur, Selangor, Pahang, Perak, Negeri Sembilan, Terengganu, Johor, Melaka, Pulau Pinang, Kelantan and Kedah (UNHCR, n.d. (b)). Most of the centres were housed in old buildings and shophouses or commercial areas, unnoticeable and hidden from the view. In some schools, volunteer teachers taught children. In Rohingya communities, girls were often expected to stay at home, take care of their siblings and help their mothers. Thus, they did not have opportunities to study. There were some Rohingya girls whose marriages were solemnised when they were just 14 years old (Mayberry, 2015). The UNHCR claimed that the major challenges included lack of certification and access to public examinations; high turnover of a teacher who worked on minimal compensation; security and protection issues faced by teachers and students at schools and outside; and lack of data out of school children.

Ronald Sutedja, an NGO working with the Malaysian Social Research Institute, said that Malaysia was 'a 'living hell' for refugees" and it was not a good choice of people to come to Malaysia (Sayed \& Choi, 2018, February 5). Their choice of Malaysia results in serious damages to their children. Of the total estimated refugee's children, only thirty per cent go to mostly to faith-based charitable NGOssupported by UNHCR. The quality of education is a serious concern where teachers are often reported absent. In the result of social, political and economic is- 
sues, a few schools going children abandon education and join irregular work in the construction, malls and restaurants minimum for 12 hours a day. Families did not have proper work and income support. Thus, they also become the reason for getting the child to abandon the school. At their congested and overcrowded apartments, the willing children were unable to do the homework in a quiet place (Sayed \& Choi, 2018, February 5). Refugee children did well in their schools, but it did not help them resolve their problems related to their refugee status and get proper works. In the poorresource schools, teachers only spoke and taught in English or Malayu, and the older students did not understand it, which resulted in their transfer to lower grades with younger children, which discourages and demotivated many refugee children (Sayed \& Choi, 2018, February 5). Teachers and children were arrested on their way to and from school (Sayed \& Choi, 2018, February 5). Since refugee children had no legal support to get a quality education in public schools; conditions forced many children to join factories and other forms of unskilled work (Wurscher, 2018).

\section{Refugee Children's Right to Health}

As per Article 24 of the UNCRC, health and healthy life is the fundamental rights of every child irrespective of its nationality or status. But in Malaysia, refugee and asylum-seeking children had no access to health care systems (Pak, 2015). However, the registered refugees got a 50 per cent fees waiver at government health centres; the cost of health care was excessively higher. In the case of asylumseeking and migrant workers' children, the fee was fully charged on foreigner rates. Many refugee or asylum-seeking and migrant worker families avoided accessing health care because of the authorities' fear of harassment, arrest, and detention. In the absence of mental health professions, the mental health needs of asylum-seeking, refugees, and migrant workers, children were mostly ignored (Child Rights Coalition Malaysia, 2012).

For local Malaysians, stateless and migrant children were responsible for various social ills. These children were uneducated. Thus many among them were involved in drug addicts, and they stole and robbed (Chou \& Gooch, 2016). How to solve their problems, when the overall social and political structures deprive them of the fundamental rights and services such as education, health, development, protection, and livelihoods? Therefore, they possibly turned out to be ills in society. When they grow up in full of the fear (risk) environment and with poverty, they probably resort to social ills to state their hunger. They were largely involved in begging, sniffing gum and finding food in the garbage. Many of the stateless boys used glue so that they could sleep well with empty stomachs (Chou \& Gooch, 2016). Chuah et al. (2018) found out that refugees and asylum seekers' health needs were complex embedded in social, cultural and economic determinants, which were further constrained by the legal environment. They found that once they arrived in Malaysia, they have had limited access to comprehensive health care. They also found that the main barriers to access healthcare were poor understanding of health issues, lack of awareness of their rights to health and healthy life, and language and culture differences. In a result of poor access to public healthcare, they were facing detrimental impacts on their mental and physical health.

Analysis

Irrespective of the nationality, all human beings are guaranteed fundamental human rights by international the law as enshrined the UN Charter of 1945. The UDHR (Universal Declaration of Human Rights of 1948) guarantees the rights of 
Available Online at https://journal.unismuh.ac.id/index.php/otoritas

Otoritas : Jurnal Ilmu Pemerintahan, 10 (2), October 2020, 111

nationality to everyone (Article 15). Articles 7 and 8 of the UNCRC recognise the child's rights to nationality. The Convention on the Status of Stateless Persons (1954) and the Convention on the Reduction of Statelessness (1961) also calls for the protection of stateless individuals and a decrease in statelessness. Regardless of these safeguards, ground realities are different for stateless, asylum seeker and refugees families and their children. They are denied their basic human rights because they are not recognised as citizens of a country (UNHCR, 2008). Malaysia has not a signed the refugee convention (1951) and its Optional Protocol (1967), but the Pakatan government had promised in its manifesto that it would ratify the International Convention on Refugees 1951 if it came into power (Bedi, 2018 (b), June 25).

Table 2 shows that Malaysia is far behind to comply with the Committee's recommendations and provisions in the UNCRC related to refugee and asylumseeking children. However, Malaysia has

Table 2. Major Indicators of Malaysia's Compliance with the UNCRC (Related to Refugees) Source: Processed by the Authors (2020)

\begin{tabular}{|c|c|c|c|}
\hline No & Major Indicators & $\begin{array}{l}\text { Reference to the child rights } \\
\text { framework }\end{array}$ & Yes or No \\
\hline 1 & $\begin{array}{l}\text { Ratified the Convention on the } \\
\text { Status of Refugees } 1951\end{array}$ & $\begin{array}{l}\text { The Committee's CoRs: in } \\
\text { paragraph } 81\end{array}$ & No \\
\hline 2 & $\begin{array}{l}\text { Ratified Optional Protocol } \\
\text { related to the Convention } \\
\text { Relating to the Status of } \\
\text { Refugees } 1967\end{array}$ & $\begin{array}{l}\text { The Committee's CoRs: in } \\
\text { paragraph } 81\end{array}$ & No \\
\hline 3 & $\begin{array}{l}\text { Ratified Convention relating to } \\
\text { the Status of Stateless Persons, } \\
1954\end{array}$ & $\begin{array}{l}\text { The Committee's CoRs: in } \\
\text { paragraph } 81\end{array}$ & No \\
\hline 4 & $\begin{array}{l}\text { Ratified Convention on the Re- } \\
\text { duction of Statelessness, } 1961\end{array}$ & $\begin{array}{l}\text { The Committee's CoRs: in } \\
\text { paragraph } 81 \text { and } 82\end{array}$ & No \\
\hline 5 & $\begin{array}{l}\text { Malaysian Child Act of } 2001 \\
\text { protects refugees and asylum } \\
\text { seeker children's rights }\end{array}$ & $\begin{array}{l}\text { Article } 22 \text { of the UNCRC } \\
\text { The Committee's CoRs: in } \\
\text { paragraph } 81 \text { and } 82\end{array}$ & No \\
\hline 6 & $\begin{array}{l}\text { Measures to stop } \\
\text { discrimination in the law }\end{array}$ & $\begin{array}{l}\text { The Committee's CoRs: in } \\
\text { paragraph } 81\end{array}$ & No \\
\hline 7 & $\begin{array}{l}\text { Measures to stop } \\
\text { discrimination in practices }\end{array}$ & $\begin{array}{l}\text { The Committee's CoRs: in } \\
\text { paragraph } 31,81 \text { and } 82\end{array}$ & No \\
\hline 8 & $\begin{array}{l}\text { Measures to stop the detention } \\
\text { of refugee and asylum-seeking } \\
\text { children }\end{array}$ & $\begin{array}{l}\text { Article } 22 \text { of the UNCRC } \\
\text { The Committee's CoRs: in } \\
\text { paragraph } 81 \text { and } 82\end{array}$ & No \\
\hline 9 & Measures to provide education & $\begin{array}{l}\text { The Committee's CoRs: in } \\
\text { paragraph } 83,84\end{array}$ & Nominal \\
\hline 10 & $\begin{array}{l}\text { Measures to provide health } \\
\text { care }\end{array}$ & $\begin{array}{l}\text { The UNCRC Article } 23 \text { and } \\
24\end{array}$ & Nominal \\
\hline 11 & $\begin{array}{l}\text { Allocation of funds for the } \\
\text { protection of vulnerable groups }\end{array}$ & $\begin{array}{l}\text { The Committee's CoRs: in } \\
\text { paragraph } 24\end{array}$ & Not assessable \\
\hline 12 & Cooperation with the UNHCR & & Yes \\
\hline
\end{tabular}


taken many positive steps.

All refugees, asylum seekers, migrants or undocumented migrant remain vulnerable to detention. In September 2014, the Human Rights Commission of Malaysia (famous as Suhakam) found 1,196 children in 12 immigration detention centres during its visit. Some of them were unaccompanied and incarcerated, along with adults (Mayberry, 2015). On the one hand, the state apparatuses have little positive initiatives towards refugees; the masses also do not treat them normal human beings but labelled as illegal and undocumented, which force them to live on the margins of society. They are not allowed to work, get a formal education and access public health care (Lik, 2017).

Such children's best interests (one of the primary principles of the UNCRC) are not taken into decisions involving asylumseeking, refugee, and stateless or undocumented children (Allerton, 2014). These children were continued to be neglected in the prevention and response systems and mechanisms because they did not have legal status (Child Rights Coalition Malaysia, 2012; Goh, 2018, January 11). Twelve years down the road to the Committee's recommendations to Malaysia in February 2007 and seven years to the deadline to submit the combined report in 2012, this paper finds that Malaysia was unable to comply with the Committee's recommendations related to migrant and refugee children and also to the long list of articles in the UNCRC and the guidelines in General Comment No 6. Malaysian has neither submitted the report nor adequately taken measures to protect the rights of refugee, and asylum seekers children in light of the Committee's recommendations and the UNCRC. However, the situation had worsened with an increasing number of these children over time. Malaysia was reluctant to ratify the relevant refugee convention and the protocol and appears to be scared of overcrowding of migrants, asylum seeker and refugees in the country, especially in its labour markets.

Refugee, asylum-seeking, and stateless children face multiple forms of discrimination due to their status in Malaysia. They faced discrimination and bullying as an outcome of their status in Malaysia. They had extremely limited access to education, and health care rather was prone to different kinds of violations, abuses, and exploitations. They have serious problems with birth registration and accessing child protection services. Due to the lack of legal framework in Malaysia, refugee and asylum-seeking children are neither acknowledged nor protected as human beings in light of Article 1 of the UNCRC. As a signatory to the UNCRC, Malaysia has ensured that children's rights are respected, regardless of their immigration status and nationality to uphold its international obligations. The Malaysia Child Act of 2001 also recognises that all children in Malaysia have the right to protection and support in every aspect and condition irrespective of their sex, race, religion, colour, language, social origin or mental, physical and emotional disabilities (UNICEF Malaysia, n.d. Online). However, the Malaysian laws related to protection, education and other necessary measures have not been introduced for refugee or asylum seekers. In other words, there was no legal framework in place for the protection of asylum seeker and refugee children (Supaat, 2014). In the 98 pages long state report submitted in 2006 to the Committee, only three lines (under Article 22 for Refugee Children) were written to claim that Malaysia had been following the customary international laws to assist refugees on humanitarian grounds (Committee on the Rights of the Child, 2006).

In light of the UNCRC, Malaysia is dutybound to protect their social needs, education, and health. Malaysia has to take various steps in many directions to respect the universal human rights of mi- 
grants, asylum seeker, and refugee children. In this direction, the first stage is to recognise migrants, asylum seeker, refugees, and their children as human beings, not as risks to the country to part of human society and humanity. It should also take the Committee's relevant recommendations seriously and take administrative, legal, financial and other measures to ensure migrant, refugee and asylum seeker children's right to education, health, protection, and development. The regular and timely reporting to the Committee is one of the indicators to show the seriousness of a country towards its citizen children. In this and many other contexts, Malaysia has somehow failed to implement the UNCRC to protect and ensure the rights of Malaysian children (such as Orang Asli, see Khoso \& Vivien, 2015; ECPAT International, 2018), the matters related to non-Malaysian refugee and asylum seekers would not gain attention in Malaysian policies and laws.

\section{CONCLUSION}

We are aware that concluding a study based on secondary sources such as this should be dealt with caution. This article does not claim to be the representatives of all Malaysian refugee and asylumseeking children. However, it attempts to represent certain issues from the refugee children rights perspective (or framework). The exact number of refugee and asylum-seeking children is not known. Thus, it is least possible to gauge every aspect of refugee children's issues and problems related to their protection, development, and survival in Malaysia. We used the child rights framework (including UNCRC and the Committee's recommendations) as reference points to indicate where Malaysian refugee and asylum seeker children stood in the country's growing economy.

The analysis reveals that Malaysia has to come forward quickly to ensure the rights of refugee and asylum-seeking chil- dren, who have gone through tortures, sufferings, and traumas in their home countries. The non-implementation or non-compliance with article 22 of the UNCRC is a major obstacle in ensuring refugee and asylum-seeking children's rights in every aspect of life. Article 3 of the UNCRC about the child's best interest has not been made part of the decisions and policies affecting refugee and asylumseeking children. It also reveals that Malaysia's refugee and asylum-seeking children are neither the rights holders nor the duty bearers appear to be accountable in such children's cases. It implies that the UNCRC and the refugee children rightsrelated provisions in other laws have not been used as procedural guarantees to determine the refugee status. In the Malaysian child protection system, the important concern is the uneven treatment and policies governing refugee and asylum-seeking children, which have not gained attention in Malaysia. Thus, letting the refugee and asylum-seeking children be deprived of fundamental health and education services. The analysis has also revealed that the two mandate-holders (UNICEF and UNHCR) have not specified their roles to ensure the realisation of refugee and asylum-seeking children's rights.

However, the ground realities show that every day, thousands of refugee and asylum-seeking children are far away from the ideal childhood life as a period of protection, safety and development. These children require humanitarian assistance based on the human rights principles of best interests and nondiscrimination since they are forced to flee from political repression and conflict. In Malaysia, refugee and asylum-seeking children's difficult experiences show serious deficiencies and problems in the state's functions. Rather, the child rights provisions for refugee and asylumseeking children (and advocacy by the international community on refugee chil- 
dren's rights) have created more challenges for the refugee and asylum-seeking children and their families. The UNCRC once ratified does not give a choice Malaysia, but Malaysia is living with a stark choice to pursue its national interests instead of taking the responsibility of badly affected minor souls by the wars, repressions, and conflicts in their homes countries.

The article might appear to be a chunk of newspaper reportage, but under the child rights framework, this chunk provides an adequate context of/for textual analysis of voiceless refugee and asylum-seeking children's rights. It has adequately helped to pinpoint all the normative (human rights) dimensions correlated with the social, cultural, political, and economic realities (related to laws, policies, financial allocations, and administrative measures in Malaysia), which refugees and asylum-seeking children are facing in Malaysia. The assessment through this framework has enabled to understand Malaysian refugee and asylumseeking children's rights in the way these are texted (or inter-textualised) by the international community. It also helped to understand that the broader practices of social and political exclusion by the host country have rendered these children dangerous and also have shaped their experiences of political and social exclusions.

\section{ACKNOWLEDGEMENT}

We extend our sincere gratitude to the University of Malaya, Malaysia for providing us with the financial support during research of this article.

\section{REFERENCES}

Acciaioli, G., Brunt, H., \& Clifton, J. (2017). Foreigners everywhere, nationals nowhere: Exclusion, irregularity, and invisibility of stateless Bajau Laut in eastern Sabah,
Malaysia. Journal of Immigrant \& Refugee Studies, 15(3): 232-249.

Aiman, A. (2018, October 1). UN expert urges Malaysia to do more on stateless children, underage marriage. Retrieved from https:// www.freemalaysiatoday.com/ category/nation/2018/10/01/un -expert-urges-malaysia-to-domore-on-stateless-childrenunderage-marriage/

Allerton, C. (2014) Statelessness and the Lives of the Children of Migrants in Sabah, East Malaysia. Tilburg Law Review: Journal of International and European Law, 19 (1-2), 26-34.

Allerton, C. (2017). Contested statelessness in Sabah, Malaysia: irregularity and the politics of recognition. Journal of Immigrant \& Refugee Studies, 15(3): 250-268.

Allerton, C. (2018). Impossible children: illegality and excluded belonging among children of migrants in Sabah, East Malaysia. Journal of Ethnic and Migration Studies, 44 (7): 1081-1097.

Azizan, H. (2018). The state of statelessness. The Star. Retrieved from https:// www.thestar.com.my/news/ nation/2018/04/01/the-state-ofstatelessness-for-those-born-inmalaysia-but-without-acitizenship-their-life-is-left-i/

Bedi, R. S. (a) (2018, October 17). More than 1000 children detained in Immigration centres this year. Retrieved from https:// www.thestar.com.my/news/ nation/2018/10/17/immigration 
-dept-has-over-1000-children-indetention-centres/

Bedi, R. S. (b) (2018, June 25). UNHCR: Allow refugees to stay and work in Malaysia. Retrieved from https://www.thestar.com.my/ news/nation/2018/06/25/unhcr -allow-refugees-to-stay-and-work -in-malaysia/

Bernama. (2019, June 19). Yemeni refugee group conveys memorandum to UNHCR. Retrieved from http:// www.bernama.com/en/ news.php?id=1737030

Borneo Post. (2016 December 31). Rohingya refugees in Malaysia remain stateless. Retrieved from https:// www.theborneopost.com/2016/1 2/31/rohingya-refugees-inmalaysia-remain-stateless/

Child Rights Coalition Malaysia. (2012). Child Rights Coalition Report on Children Rights in Malaysia. Retrieved from https:// www.unicef.org/malaysia/ Child Rights Coalition Report on Childrens Rights FINAL.pdf

Chou C. T. \& Gooch, L. (2016). Malaysia's invisible children. Retrieved from http://www.aljazeera.com/ indepth/features/2015/04/ malaysia-invisible-children150429064406390.html

Chuah, F. L. H., Tan, S. T., Yeo, J., \& LegidoQuigley, H. (2018). The health needs and access barriers among refugees and asylum-seekers in Malaysia: a qualitative study. International journal for equity in health, 17(1): Doi: $\underline{10.1186 / s 12939-018-0833-x}$
Committee on the Rights of the Child. (2005). GENERAL COMMENT NO. 6 (2005): Treatment of unaccompanied and separated children outside their country of origin. Retrieved from https:// www2.ohchr.org/english/bodies/ crc/docs/GC6.pdf

Committee on the Rights of the Child. (2006). State Party Report: Malaysia. Retrieved on 16 June 2018 at https://www.unicef.org/ malaysia/CRC - 2006 Malaysia_1st_Report.pdf

Committee on the Rights of the Child. (2007). Concluding Observations and Recommendations: Malaysia. Retrieved on 16 June 2018 from http://www.refworld.org/ country ${ }_{\text {CRC }}, \mathrm{MYS}_{\text {, }} 468912822,0 . \mathrm{html}$

ECPAT International. (2018). Sexual Exploitation of Children in Malaysia (Submission) for the Universal Periodic Review of the human rights situation in Malaysia to the Human Rights Council. Retrieved from http:// www.ecpat.org/wp-content/ uploads/2018/07/UniversalPeriodical-Review-SexualExploitation-of-ChildrenMalaysia.pdf

Fong, L. F. (2019). Malaysian Bar: Unnecessary detention of refugees needs to be addressed. Retrieved from https:// www.thestar.com.my/news/ nation/2019/07/04/malaysianbar-unnecessary-detention-ofrefugees-needs-to-be-addressed

Free Malaysia Today. (2019, July 4). Deported Filipinos claim they 
Available Online at https://journal.unismuh.ac.id/index.php/otoritas

Otoritas : Jurnal Ilmu Pemerintahan, 10 (2), October 2020, 116

were treated like animals at detention centre. Retrieved from https:// www.freemalaysiatoday.com/ category/nation/2019/07/04/ deported-filipinos-claim-theywere-treated-like-animals-atdetention-centre/

Goh, M. (2018, January 11). Rohingya refugees work at unlicensed bird's nest factory in Malaysia to make a living. Retrieved from https:// www.channelnewsasia.com/ news/asia/rohingya-refugeeswork-at-unlicensed-bird-s-nestfactory-in-9852428

Human Rights Watch. (n.d.). UNHCR AT 50: WHAT FUTURE FOR REFUGEE PROTECTION? Retrieved from https://www.hrw.org/sites/ default/files/reports/pdf1.pdf

Hussin, H., \& Khoso, A. (2017). Seaweed cultivation and coastal communities in Malaysia: an Overview. Asian Fisheries Science, 30: 87-100.

Joles, B. (2018, September 25). In Malaysia, Asylum Seekers and Trauma As Currency. Retrieved from https:// www.worldcrunch.com/worldaffairs/in-malaysia-asylumseekers-and-trauma-as-currency

Kaur, A. (2007). Refugees and refugee policy in Malaysia. UNEAC Asia Papers, 18(1): 77-90.

Kaur, A. (2008). International migration and governance in Malaysia: Policy and performance. UNEAC Asia Papers, 22: 4-18.

Khairi, A. (2012). Managing the Challenges of Refugees and Their
Rights in Malaysia. Jurnal Studi Hubungan Internasional, 2(1): 112.

Khoso, A. \& Vivien, W. C. Y. (2015). Promotion and protection of the rights of Orang Asli in Peninsular Malaysia: A study of the Suhakam. Geografia Malaysian Journal of Society and Space, 11(13): 86- 95.

Kneebone, S. (2017). Australia as a Powerbroker on Refugee Protection in Southeast Asia: The Relationship with Indonesia. Canada's Journal on Refugees, 33 (1), 29-41.

Lik, F. J. (2017). The Invisible Refugees in Malaysia. Retrieved on 17 June 2018 from http://eng.tzuchi.my/ index.php/medicine/tima/timaconference-news/item/7583-theinvisible-refugees-in-malaysia

Lundy, L. (2007). 'Voice' is not enough: conceptualising Article 12 of the United Nations Convention on the Rights of the Child. British educational research journal, 33 (6): 927-942.

Lundy, L. (2012). Children's rights and educational policy in Europe: The implementation of the United Nations Convention on the Rights of the Child. Oxford Review of Education, 38(4): 393-411.

Makhtar, M., Asari, K. N., \& ML, M. Y. (2015). Right to Education for Irregular Migrant Children in Malaysia: A Comparative Analysis. Pertanika Journal of Social Sciences and Humanities, 23(S): 85-96.

Mayberry, K. (2015). Rohingya Refugee Kids: Finding a Future in Malaysia. Retrieved from http://poskod.my/ 
Available Online at https://journal.unismuh.ac.id/index.php/otoritas

Otoritas : Jurnal Ilmu Pemerintahan, 10 (2), October 2020, 117

features/rohingya-refugee-kidsfinding-a-future-in-malaysia/

Menon, J. (2017). Poor living conditions put refugees at risk. Retrieved from https://www.malaymail.com/ news/malaysia/2017/01/12/poor -living-conditions-put-refugees-atrisk/1290865

OHCHR. (n.d.: Online). Convention on the Rights of the Child. Retrieved from https://www.ohchr.org/en/ professionalinterest/pages/ crc.aspx

Pak, J. (2015). The plight of immigrant children in Malaysia. Retrieved from http://www.bbc.com/news/ $\underline{\text { business-32687113 }}$

Palansamy, Y. (2015) Malaysia will not sign UN convention on refugees, says minister. Retrieved from http:// www.themalaymailonline.com/ malaysia/article/malaysia-will-not -sign-un-convention-on-refugeessays-minister

Palansamy, Y. (2018). Why penalise Ahmadis under Shariah if considered non-Muslims? court asked. Retrieved from https:// www.malaymail.com/s/1618430/ why-penalise-ahmadis-undershariah-if-considered-non-muslims -court-asked.

Pobjoy, J. M. (2013). A child rights framework for assessing the status of refugee children. In S. Juss \& C. Harvey (eds.), Contemporary Issues in Refugee Law (Edward Elgar), pp. 91-138. University of Cambridge Faculty of Law Research Paper No. 27/2013. Retrieved from SSRN: $\quad$ https://ssrn.com/ $\underline{\text { abstract }=2304601}$
Paulsen, E. (2019). The future for refugees in M'sia. Retrieved from https://www.thestar.com.my/ news/nation/2019/06/16/thefuture-for-refugees-in-msia

Razali, R. M. (2017). Addressing Statelessness in Malaysia: New Hope and Remaining Challenges. Statelessness Working Paper Series 2017/9. Tilburg, the Netherlands: ISI. Retrieved from https://files.institutesi.org/ WP2017 09.pdf

Razali, R. M., Nordin, R., \& Duraisingam, T. J. (2015). Migration and statelessness: Turning the spotlight on Malaysia. Pertanika Journal of Social Sciences and Humanities, 23(S): 1936.

Sawyer, C. (2013). The loss of birthright citizenship in New Zealand. Victoria U. Wellington L. Rev., 44: 653-674.

Sayed, I. \& Choi, J. (2018, February 5). Inside Malaysia's 'Living Hell' for Refugee Children. News Deeply. Retrieved from https:// www.newsdeeply.com/refugees/ articles/2018/02/05/insidemalaysias-living-hell-for-refugeechildren

Siah, P. C., Lee, W. Y., \& Goh, L. Y. (2015). Quality of life among refugee children in Malaysia-a brief report. Vulnerable Children and Youth Studies, 10(4): 294-299.

Suganya, L. (2013, October 6). Government urged to end detention of child refugees. Retrieved from www.thestar.com.my/news/ nation/2013/10/06/stop-child- 
Available Online at https://journal.unismuh.ac.id/index.php/otoritas

Otoritas : Jurnal Ilmu Pemerintahan, 10 (2), October 2020, 118

detention/

Supaat, D. I. (2014). Refugee Children under the Malaysian Legal Framework. UUM Journal of Legal Studies, $X(4)$ : 118-148.

Tan, R. (2017). Only 300 refugees registered so far. The Star. Retrieved from https:// www.thestar.com.my/news/ nation/2017/08/03/0nly-300refugees-registered-so-far-ministry -may-have-to-track-down-the150000-unhcr-cardholders/

The Star Online. (2018, October 21). UNHCR: They're asylum seekers. Retrieved from https:// www.thestar.com.my/news/ nation/2018/10/21/unhcr-theyreasylum-seekers-myanmar-chinfeatured-in-rage-report-dont-meetinternational-definition/

Today Online. (2018, December 12). Stateless boy in Malaysia always prays for IC before attending court: Grandmother. Retrieved from https://www.todayonline.com/ world/asia/stateless-boy-malaysia -always-prays-ic-attending-courtgrandmother

Tregonning, H. G. (1970). The Philippine Claim To Sabah. Journal of The Malaysian Branch of Royal Asiatic Society, 43(Part 1).

UNHCR Malaysia. (2015). National Action Plan: Malaysia. Retrieved from http://www.unhcr.org/enmy/5660000a9.html.

UNHCR. (2008). Statelessness: An Analytical Framework for Prevention, Reduction and Protection. Retrieved from http:// www.unhcr.org/en-my/ protection/

statelessness/49a271752/

statelessness-analytical-framework -prevention-reductionprotection.html

UNHCR. (2012). A Framework for the Protection of Children. UNHCR: Geneva.

UNHCR. (2013). For the Office of the High Commissioner for Human Rights' Compilation Report-Universal Periodic Review: MALAYSIA. Retrieved on 2 June 2018 from http://www.refworld.org/ pdfid/513d9a0e2.pdf

UNHCR. (2014). Global action plan to end statelessness: 2014-24. Retrieved from http:// www.unhcr.org/54621bf49.html

UNHCR. (2017). Figures at a glance: Know your numbers. Retrieved from https://www.unhcr.org.my/ About Us-@Figures At A Glance.aspx.

UNHCR. (n.d). (a). Refugee Facts. Retrieved from https:// www.unrefugees.org/refugeefacts/what-is-a-refugee/

UNHCR. (n.d.) (b). Education in Malaysia. Retrieved from http:// www.unhcr.org/en-my/educationin-malaysia.html

UNICEF Malaysia. (n.d.: Online). Child Act 2001. Retrieved from https:// www.unicef.org/malaysia/ protection child-act-2001.html

UNICEF. (2006). General Comments of the Committee on the Rights of the Child. Florence, UNICEF Innocenti Research Centre. 
Available Online at https://journal.unismuh.ac.id/index.php/otoritas

Otoritas : Jurnal Ilmu Pemerintahan, 10 (2), October 2020, 119

Vandenhole, W., Desmet, E., Reynaert, D., \& Lembrechts, S. (Eds.). (2015). Routledge international handbook of children's rights studies. London: Routledge.

Vas Dev, S. (2009). Accounting for state approaches to asylum seekers in Australia and Malaysia: The significance of "national" identity and "exclusive" citizenship in the struggle against "irregular" mobility. Identities: Global Studies in Culture and Power, 16(1): 33-60.

Wurscher, I. (2018). Refugee and asylum seekers in Malaysia The consequence of invisibility. International Law Review. Retrieved from https://www.msuilr.org/ msuilr-legalforumblogs/2018/7/9/refugee-andasylum-seekers-in-malaysia-theconsequences-of-invisibility. 